\section{MuHITTIN ELİAÇIK ${ }^{* *}$}

\title{
Evliya Çelebi
} \section{Seyahatnâmesi'nin II.} Abdülhamid Döneminde
Muzır Neşriyat Sayılması

\author{
The Seyahatname of Evliya Chelebi is Considered as \\ One of Harmful Publications During Abdülhamid II
}

\section{Ö Z E T}

Osmanl ve diğer ülke memleketlerini özel veya resmî görevlerle dolaşarak yazdı̆̆ı on ciltlik Seyâhatnâme'siyle taninan Evliya Çelebi, bu eseriyle gezip gördüğ̈̈ ülke ve memleketlerin coğrafyası, folkloru ve kültür tarihi baklmından da zengin bir bilgi kaynă̆ bırakmıştır. Çă̆ının ekstrem bir yazarı olan Evliya Çelebi'nin Seyâhatnâme'si her an ve zamanda okunan sevimli bir kaynak olmakla beraber II.Abdülhamid döneminde muzır neşriyat sayılarak önce sansüre uğramış, sonra da yasak edilmiştir. Seyâhatnâme'nin ilk altı cildi 1896-1902 arasında sansür altında basılmışken, kalan ciltlerinin basımı 1902'de saraydan gelen emir üzerine muzır neşriyat sayılarak yasaklanmiştır. Muzır sayılma ve yasaklanma sebebi arşiv belgelerinde açıkça belirtilmeyip gizli ve muğlak bırakılmıştır. Bu yasakta büyük ölçüde matbaada sansür altında basilan bir kitabın bir de gazetede neşri etkili olmuş gözükmektedir. Bu makalede bu sansür ve yasakla ilgili arşiv belgeleri incelenerek sebep ve sonuçları gösterilecek, Seyâhatnâme'nin sansür edilen bölümlerine dair örnekler verilecektir.

A N A H T A R K E L İ M E L E R

Evliya Çelebi, Seyâhatnâme, II.Abdülhamid dönemi, sansür, muzır neşriyat, yasak.

\section{A B S T R A C T}

The Ottoman Turkish writer Evliya Chelebi or Çelebi who travelled extensively through the Ottoman empire and neighbouring countries, both in a private capacity and at the service of the Sublime Porte. The account of his travels is recorded in his ten-volume Turkish-language Seyâhatnâme. The Seyâhatnâme contains a wealth of information on the cultural history, folklore and geography of the countries he visited. The Seyâhatnâme which was written by Evliya Chelebi and that was known as a extraordinary author in his time had been forbidden in period of Sultan Abdiulhamid II because of mischievous publication. First six-volume of the Seyâhatnâme which was advertised by Hammer to world of science in 1815 is printed between 1896-1902 in press of Newspaper of İkdâm, under inspection of Ministry of Education; however, had been forbidden printing of other volumes with decree of palace in 1902. The cause of this prohibition hadn't been showed in the documents of archives evidently. In this prohibition had influenced especially publishing in newspaper, because this book was being printed in pres. In this priciple with this prohibit and inpection which is related to documents of archives will be showed the causes and results, The Seyehatname of whose parts was being prohibited will the examples be given.

\section{K E Y W O R D S}

Evliya Chelebi, Seyâhatnâme, Period of Sultan II. Abdiulhamid, censorship, mischievous publication, prohibition.

* Doç. Dr., Kırıkkale Üniversitesi Fen-Edebiyat Fakültesi Türk Dili ve Edebiyatı Bölümü, Kırıkkale.

** Bu makale MÜ İletişim Fakültesi'nce 9-10 Ekim 2008 tarihinde düzenlenen "Ulusal Basından Sansürün Kaldırılışının 100.Yılı Kongresi"nde sunulan bildirinin yeniden ele alınıp düzenlenmiş şeklidir. 


\section{Giriş}

Evliya Çelebi Seyâhatnâmesi 17.yüzyıl Osmanlı coğrafyasının değişik yön ve açlardan çizilmiş geniş bir tablosudur. Evliya Çelebi(16111684) padişah ve diğer devlet adamlarıyla çok yakın ilişkiler kurmasına rağmen hiçbir makam ve mevki hırsına kapılmayarak ömrünü gezip görmeye, yeni insan ve beldeler tanıyarak onları anlatmaya adamış, seyahat hatırına birçok kimseyle hoş geçinmiştir. $O$, bütün samimiliğine ve hoşgörüsüne rağmen gördüğü uygunsuzlukları da açık veya kapalı bir dille eleştirmekten çekinmemiş, devletin çöküş sebeplerini dile getirmiştir. Onun Seyâhatnâme'si her anda ve zamanda sevilmiş, beğenilmiş bir eser olmasına rağmen garip bir sebeple II. Abdülhamid döneminde ileri derecede muzır neşriyattan sayılarak yasaklanmıştır. 1293 Osmanlı-Rus harbinin olağanüstü şartlar getirdiği ileri sürülerek Kânûn-1 Esâsînnin askıya alındığı, sıkıyönetim ilan edilerek geniş bir hafiye ve jurnal sisteminin kurulduğu ve birçok ünlü eserin sansür ve yasağa uğradığ1 II.Abdülhamid döneminde Seyâhatnâme de bundan nasiplenmiş, sadece yasaklanmayıp ileri derecede muzır neşriyat sayılarak yakılanlar listesine alınmıştır. Bu dönemde sadece Seyâhatnâme'nin değil Muhammediye, Mızraklı İlmihal, Kısas-1 Enbiyâ gibi halkın el kitabı haline gelmiş eserlerin bile kütüb-i muzırra listesine alındığı görülmektedir. Üstelik Seyâhatnâme de dahil bu eserler maarif nazırının 24 Mayıs 1902 tarihli yazısının ekindeki listede yakılan kitaplar arasında da bulunmaktadır (BOA Y.MTV 230/81; Demirel 2007:184; Demirel-Çavaş, 2005:26,28). Bu sansür ve yasaklarda sansür memurlarının subjektif tutumlarının etkili olduğu göz ardı edilemez; ancak, Seyâhatnâme'ye uygulanan yasağın bizzat saraydan gelen emirle gerçekleşmesi dikkat çekicidir. Tabii ki bunda da sansür memurlarının saraya yaptığ jurnal etkili olmuştur. Böyle olmakla beraber, Yıldız'ın bu işle bu kadar yakın ilgilenmesi manidardır. Evliya Çelebi'nin ölümünden sonra özel bir kütüphanede saklanarak 55 yıl sonra İstanbul'a getirilen ve 1815 'te Hammer tarafından bilim dünyasına tanitılan Seyâhatnâme 1896'da ilk altı cildi Maârif Nezâretínin sansürü altında İkdâm Gazetesi matbaasında ciltler halinde yayımlanmaya başlanmış; ancak, ilk altı cildi çıtıktan sonra 1902'de İkdâm Gazetesi'nde de ayrıca neşredildiği gerekçesiyle saraydan gelen ikaz ve emir üzerine kalan ciltlerin basımı yasaklanmıştır. 


\section{OSMANLI DEVLETI'NDE SANSÜR}

Matbaanın ülkeye girişiyle başladığı görülen sansürün Osmanlı Devleti'nde gerçek anlamdaki uygulamalarının Tanzimat dönemiyle başladığ1 görülmektedir. Osmanlı yönetiminin basının gücünü farketmesiyle devletin resmî görüş ve isteklerini yansıtmak üzere 1831'de Takvîm-i Vekâyi çıkarılmış, bununla yetinilmeyip başka gazetelerden de yararlanılarak 1840'da devletin yardımıyla William Churchill adlı bir İngiliz tarafından Cerîde-i Havâdis yayımlanmış ve devlet bu yolla Avrupa ülkeleriyle gayrimüslim Osmanlı cemaatlerine kendi görüşlerini aktarma fırsatı bulmuştur. Ancak, 1840'lı yıllarda İzmir ve İstanbul'da yayınlanan Rumca, Ermenice, Ladino ve Bulgarca gazetelerin etkin bir kamuoyu oluşturmasıyla Osmanlı yönetimi basını kontrol etme çabalarına girmiş ve 1857 'de ilk sansür düzenlemesi olan matbaa nizamnâmesi çıkarılmıştır. Buna göre matbaaların basacakları kitap ve risaleler muzır olup olmadıkları Meclis-i Maârif tarafından incelenip Sadaret'ten izin alındıktan sonra basılmıştır (Demirel 2007:31). Devlet eliyle başlatılan basın yolunun özel teşebbüsçe de kullanılmasıyla 1860'da Agâh Efendi Tercüman-1 Ahvâl'i, 1862'de de Şinasi Tasvîr-i Efkâr'1 ç1karmış, Tasvîr-i Efkâr'da Osmanlı aydınları ülke ve hükümet sorunlarını irdelemeye başlayınca bir kamuoyu oluşmaya başlamış ve bu gelişmeleri yakından izleyen hükûmet 1864 'te muhalif yayınları engellemek üzere II. Abdülhamid dönemi sansür uygulamalarının temel dayanağı olan ve III. Napolyon döneminde Fransa'da uygulanan basın kanununa dayanan matbûât nizamnâmesini çıkarmış ve bu nizamnâme 1909'a kadar yürürlükte kalmıştır (Demirel 2007:33). Bu nizamname hakkında Fransa'nın ünlü idare hukukçusu A. Batbie'nin 1885'te “Böyle bir sansür rejimi Fransa için geriletici etkilerde bulunursa da Rusya ve sultanın ülkesi için bir ilerlemedir" demiştir (Ortaylı 1995:176-177). Osmanlı yönetimi bu nizamnâmeyle yetinmeyip 1867'de âlî kararnâme ile basına karşı daha sert tedbirler alınca birçok aydın yurtdışına kaçarak Avrupa'nın çeşitli şehirlerinde Muhbir, Hürriyet, Ulûm, İttihad gibi gazeteleri yayınlamış ve böylece sürgünde bir Türkçe basın ortaya çıkmış, 23 Aralık 1876'da II. Abdülhamid'in ilan ettiği Kânûn-1 Esâsî ile basın kısa bir süre nefes almışsa da 1864 tarihli matbûât nizamnâmesi yürürlükte olduğundan sansür yine yüzünü göstermiş, 1877'de başlayan Osmanl1-Rus Savaş1 
üzerine Kânûn-1 Esâsî'nin "ihtilâl ihtimâlinde hükûmetin sıkıyönetim ilanı ve emniyeti bozanların yurtdışına sürgünü" yolundaki 113. maddesi uygulanmış ve ayrıca 36.maddeye dayanılarak sıkıyönetim ilan edilmiştir. Kararnâmede yer alan "hükûmet-i askeriyye tahdîş-i ezhânı mûcib neşriyâtda bulunan gazeteleri derhâl tatil etmeğe ve bu cemiyetleri men etmeğe mézûndur" maddesiyle mebuslar ve gazeteciler çeşitli yerlere sürülmüş ve Rus harbinin olağanüstü şartlarında II. Abdülhamid halkın meclisli bir hayata henüz hazır olmadığını ileri sürerek 13 Şubat 1878'de Meclis-i Meb'ûsân'ı kapatmıştır. Sıkıyönetim savaş sonrası nispeten kalksa da basın için devam etmiş, 1857 tarihli matbaa nizamnâmesi kaldırılıp 1888'de matbaalar nizamnâmesi hazırlanmış, sonra bu nizamnâme de kaldırılıp 1894'de 1909 tarihli matbaalar kanununa dek yürürlükte kalan matbaalar ve kitapçılar nizamnâmesi çıkarılmıştır (Demirel 2007: 37-39).

\section{SEYÂHATNÂME'NINN SANSÜRÜ}

1640`da ilk seyahatine çıkıp ömrü boyunca Osmanlı İmparatorluğu'nun dört bir yanını ve Osmanlı'nın rakibi olan büyük ülkeleri gezip dolaşarak Seyâhatnâmésini yazan ve gördüğü uygunsuzlukları da açık veya kapalı bir dille eleştirmekten çekinmeyen Evliya Çelebi, 1671'de hac dönüşünde Mısır'a geçmiş ve kalan ömrünü orada geçirmiştir. Onun ölümünden sonra Mısır’da özel bir kütüphanede saklanarak 55 yıl sonra İstanbul'a getirilen ve 1815 'te Hammer tarafından bilim dünyasına tanıtılan on ciltlik Seyâhatnâme'si ilk olarak 1848'de Kahire'de Bulak Matbaasında Müntehâbât-1 Evliyâ Çelebi adıyla yayınlanmıştır. 1896-1902 arasında ilk altı cildi Pertev Paşa nüshası esas alınarak İkdâm Gazetesi matbaasında basılmışsa da 1902'de muzır yayın sayılarak basım ve dağıtımı yasaklanmiştır. 7. ve 8. ciltler 1928'de Türk Tarih Encümeni'nce, 9-10. ciltler ise 1938 'de MEB tarafından yayımlanmıştır. ${ }^{1}$ II. Abdülhamid döne-

1 Tamamı 10 cilt olan Seyâhatnâme'nin ilk altı cildi İkdam Gazetesi'nde Pertev Paşa nüshası esas alınarak Ahmet Cevdet ve Necip Asım tarafından basılmış, 6. cildin basımına ise Macar bilimler akademisi yardım etmiştir.(C. 1-4, İstanbul 1896,. C. 5 1897, C. 6 1900) 7.-8. ciltler 1928'de Türk Tarih Encümeni'nce Kilisli Rifat'ın gözetiminde bastırılmıştır. 9-10. ciltler ise 1935-1938'de Maarif Vekaleti'nce yeni harflerle bastırılmıştır. İlk altı cildin basımı II.Abdülhamit dönemine rastladığından birçok 
minde kitapların basım ve yayımı Maârif Nezâreti'nde Telif ve Tercüme Dairesi kurularak, daha sonra da Encümen-i Teftiş ve Muayene Kurumu oluşturularak denetlenmiştir (Demirel 2007:90). Kitaplara basım izni verilmemesi genellikle dinî, ahlâkî ve siyâsî sebeplere dayanmış, bazen de hiçbir açıklama yapılmamıştır. Maârif Nezâreti'nin izniyle sansürden geçerek basılan kitaplar bir süre sonra muzır sayılarak yasak kitaplar listesine alınabilmiş, Evliya Çelebi Seyâhatnâmesi de bu şekilde sansür ve yasağa uğramıştır. Konuyla ilgili arşiv belgelerinde muzırlık sebebi belirtilmemiş ve sadece "..bunun ne gibi fıkarât-1 muzırrayı muhtevî olduğu ma'lûm bulunmasına mebnî.." denilmiştir.² Seyâhatnâménin muzır sayılıp yasaklanması konusuna girmeden önce, sansür edilen bölümler hakkında kısaca bilgi vermek istiyoruz.

Seyâhatnâme'nin İkdâm Gazetesi'nde sansür altında basılan ilk altı cildi M. Nihat Özön tarafından yazma bir nüshayla karşılaştırılmış ve sansürce çıkarılan parçalar ayrı bir cilt halinde yayımlanmıştır. ${ }^{3}$ Seyâhatnâme'den sansürce çıkarılan bölümlerin arşiv belgelerinde açıkça gösterilmemesi sebebiyle sansürlenen bölümleri bu şekilde ortaya koymaya çalışacağı. Yayımlanan bu ciltte sansürlenen bölümlerin hepsinin bulunmayabileceğini de düşünüyor; ancak sansürün niteliği hakkında da yeterli kanaate ulaştığımızı belirtmek istiyoruz. Seyâhatnâme'den sansürce çıkarılan bölümler, eleştirme okunan ve yönetime dokunan bölümler olarak nitelenebilir. Özön, bu cildin önsözünde Seyâhatnâme'den yapılan çıkarmaların sağlam bir esasa dayanmadığını, çıkartılan bölümlerin aynı tipte bir muzırlık göster-

parçalar sansür nedeniyle çıkarılmıştır. Daha sonra Seyâhatnâme Reşat Ekrem Koçu(Evliya Çelebi Seyâhatnâmesi, 5 cilt, 1943-1951), Mustafa Nihat Özön (Seyâhatnâme, Onyedinci Asır hayatından Levhalar, 3 cilt, 1944-1945), Zuhuri Danışman (15 cilt, 1970-1976) ve Nihal Atsız (2 cilt, 1962) tarafından kısaltılmış-seçilmiş parçalar halinde yayınlanıp, son olarak YKB yayınları arasında 199-2005 arasında çeşitli ciltler hâlinde (yayında hizmeti bulunanlar: S. Ali Kahraman, Yücel Dağlı, Robert Dankoff, Zekeriya Kurşun, İbrahim Sezgin) yayınlanmıştır. Ayrıca, M. Nihat Özön'ün oğlu Nijat Özön tarafından da hazırlanmıştır (2006, Kabalcı Yayınevi)

2 BOA, DH.MKT 585/3.( Yıldız sarayı başkitâbet dairesinden Matbûât-1 Dâhiliye Müdiriyetine yazılan tezkere)

3 M. Nihat Özön, Seyâhatnâme- "17.asır hayatından levhalar", 3 cilt(191+235+176 sf.) Ankara, Akba Kitabevi, (t.y.) 
mediğini ve muzır sayılıp çıkarılan bölümlerin başka baskılarda yer aldığını ifade etmektedir. Yukarıda belirtildiği üzere basılacak bir kitabın kaderi teftiş memurunun iki dudağı arasında bulunuyordu ve bir yerde muzır görülerek çıkarılmış bölüm bir başka yerde atlanabiliyordu. Meselâ, Özön önsözde Seyâhatnâme'nin birçok yerinde $M u$ rad kelimesinin (muhtemelen o devirde tahttan indirilmiş ve yaşamakta olan Sultan Murad ismini andıracağı için) değiştirilmiş olduğunu, ama bazı yerlerde kaldığını söylemektedir. Özön'ün bu eseri incelendiğinde, sansürde özellikle zulüm tasvirlerinin çıkarıldığı dikkati çekmektedir. Meselâ ilk ciltlerde Defterdarzâde Mehmet Paşa'nın Erzurum'dan çıkıp celâlî olarak yollarda dolaştığı sırada Çorum taraflarında kışın adamlarının halka yaptığı zulümlerin anlatıldığı bölümde, Bardaklı Baba türbesini ziyaret bahsinde "paşalı celâlîlerinin zulümlerinden yakınmayı anlatan" parağrafın sansürce çıkarıldığı görülmektedir. Aynı şekilde Karahaydaroğlu bahsinde "onun Küçük Çavuş Paşa'yı yakalamasının ve yapılan zulmün tasvir edildiği” bölüm de sansürce çıkarılmıştır.

M. Nihat Özön'ün eserinin ${ }^{4}$ sansüre ait cildinden hareketle, Seyâhatnâme'nin ilk altı cildinden sansürce çıkarılan bölümlere ait birkaç örnek vermek istiyoruz:

Defterdarzâde Mehmet Paşa hakkındaki tafsilât arasında, matbah dairesinin bir özelliği görülerek ayrıntılıca anlatıldığı bölümü çıkarılmıştır.

Defterdarzâde Mehmet Paşa'nın Lâdik yakınlarında Körköy'de konakladı̆̆̆ strada İstanbul'dan gelen ulakları hapsedip eşyaların aratması, bir şey bulamamasi ve daha sonra koyverdiğgi bu ulakların çok sevdiğgi Murtaza Paşa'nın kesilmiş kellesini getirmelerinin ayrıntılarının anlatıldığı bölüm çıkarılmışıır.

Ankara civarında İstanoz köyünde görülen cambaz seyrinin anlatımı, sansürce bir çıkarma olmasa da mânâyı karıştıracak kadar değiş̧tirilmiştir.

Defterdarzâde'nin İstanoz köyünde konaklarken Varvar Ali Paşa'dan aldığı uzunca mektup çok kısaltılmış ve özellikle celâlî isyanlarına dair dikkat çekici noktalar bulunan Defterdarzâde'nin cevabı tamamen çıkarılmıştır.

M. Nihat Özön, 17.asır hayatından levhalar, 3. cilt (176 sf., sansürce çıkarılmış parçalar). 
Köprülü Mehmet Paşa'nın Varvar Ali Paşa tarafindan nasıl mağlup edilip zincire çekildiğinin anlatıldı̆̆ı bölüm çıkarılmıştır.

Varvar Ali Paşa Köprülü'yü yenince artık gururdan Defterdarzâde'ye aldırış etmemiş, Defterdarzâde de onun bu hareketini anlamazliktan gelerek mektup yazmaya hazırlanmıştır. Bu sırada İstanbul'dan memurların gelmesiyle oluşan sahne çıkarılmıştır.

İpşir, Varvar Ali Paşa'yı basıp bozduktan sonra Köprülü'yü zincirden kurtararak Varvar'la da yüzleştirmiştir. Korkunç oyunun canlı sahnelerinden olan bu karşılaşma kısmından mânâyı bozan çıkarmalar yapıldığı gibi, acı bir konuşma da tam olarak çıkarılıp sadece "Mecliste birbirine olmaz lakırdılar söylediler" diye yazılmıştır.

Defterdarzâde olaylardan sonra dolaşarak Beypazarı'na vardığında Evliya Çelebi'nin babasının öldü̈̆̈̈̈ne ve eşya ve mallarının kadınların ellerinde kaldığına dair haberler gelmiş ve Evliya Çelebi işlerini düzeltmek için izin alarak İstanbul'a gittiğinde birçok önemli olaylara şahit olmuştur. İstanbul'dan Varvar Ali Paşa'yı kışkırtanlar onun ölümüyle fikirlerinden vazgeçmeyip bu kez maksatlarına ulaşmak için başka yollar aramışlar ve İbrahim'i tahttan indirmişlerdir. Bu kısımların çoğu sansürce çıkarılmıştır.

İbrahim'in tahttan indirilip öldürülmesiyle, fevkalâdeden yapılan ve adet üzere yedi yılda bir olan saraydaki adamların sipahilikle dışarı çıkma işi bu kez büyük bir karışıklı̆̆a sebep olmuş ve asıl sarayla Galatasaray ve İbrahim Paşa saraylarının içağaları zorbalığa kalkışmışlardır. Dışarıdaki eski sipahilerden de

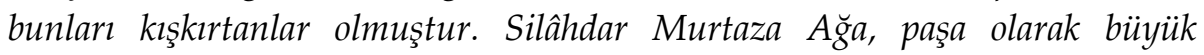
çıkmabaşılık ile Şam valisi tayin edilmiş, Evliya Çelebi de paşanın müezzini olarak onun yanında Şam'a gitmeye hazırlanırken Sultanahmet meydanında toplanan sipahilerin üzerine yeniçerilerin hücum ettiğine şahit olmuştur. Evliya Çelebi bu olayı uzun uzadıya anlattı̆̆ı halde büyük bir kısmı, özellikle de vuruşma sahneleri sansürce çıkarılmıştır.

Evliya Çelebi Şam'dan Murtaza Paşa'nın ulaklığıyla İstanbul'a geldiğinde şehri karışıklık içinde bulmuştur. Buna göre, Anadolu'da toplanmış celâlîler Üsküdar'a gelmekte, İstanbul'dan da takım takım asker Üsküdar'a geçirilmektedir. Halkın bu cengi seyretmek için merakla sokağa dökülüşünün anlatıldığı kısım sansürce çıkarılmıştır. 
Evliya Çelebi Melek Ahmet Paşa Van valisi iken bazı işlerin halli için İran ve Irak'a gitmiş, dönüşünde daha dinlenmeden İstanbul'dan gelen haberler üzerine Melek Ahmet Paşa yakın bir adamı olmasından dolayı Evliya Çelebi'yi ulaklıkla İstanbul'a göndermiştir. İstanbul'da sadrazam değiş̧ip kul ayaklanmış ve fenalıklarm başı olarak tanınan kimselerin başları istenmiştir. İstenenlerden çoğu da sarayın ileri gelen adamlarıdır. Evliya Çelebi'nin bu sırada gördükleriyle işittiklerini kaydettiği beş altı sayfalık kısım sansürce çıkarılmıştır.

Evliya Çelebi, Melek Ahmet Paşa Van valiliğinden azledildiğinde ondan kalan bazı vergileri almak üzere Bitlis hanının yanına gittiğinde eski hanın gelmesi üzerine durumun değiştiğgini görerek hapis gibi kalmış ve oradan kaçma çarelerini araştırırken odasında birlikte uyuduğu genç Bitlis hanının, kardeşi tarafindan öldürülmesi olayına şahit olmuştur. Bu olaym ayrıntılı olarak anlatıldığı bölüm sansürce tamamen çıkarılmıştır.

Evliya Çelebi'nin, Melek Ahmet Paşa'nın sadrazamliğında işlerin bozulmasına dair kaydettiği olaylardan birisi olan Hanefi Halife ve Dasnik Emirze'nin başına gelenlerin anlatıldı̆̆ı bölümde mânâyı epey bozacak çıkarmalar yapılmıştır.

İşte, Seyâhatnâménin muzır sayılıp yasaklanması yukarıdaki sansürlenmiş örneklerden dolayı olmuştur. Her ne kadar ilk altı cildinin basımına izin verilmiş olsa da sonradan hem sansürün daha da ağırlaşması, hem de eserin ayrıca İkdâm Gazetesi'nde de neşredilmesi sebebiyle ikinci altı cildin basımı yasaklanmıştır. Bu yasakta hiç şüphesiz mevcut iki aşamalı sansür denetimine 1901'de Matbûât-1 Dâhiliye Müdîriyeti'nin de eklenmesiyle denetimin iyice ağırlaşması etkili olmuştur. Zaten 1902'de Dâhiliye ve Maârif Nezâreti memurlarınca kütüphaneler, kıraathaneler, kitapçı dükkânları ve gazete idarehanelerindeki kitap veya gazete koleksiyonları didik didik incelenerek yasak kitaplar belirlenmiş ve bu teftişlerde yayınların dinî yönden sakıncası ve devlet aleyhinde olup olmadığına, kanunlara uygunluğuna, ahlâka aykırılık taşıyıp taşımadığına bakılmıştır. Seyâhatnâme'nin yasaklanması da bu denetimler sırasında olmuştur. Bu arada bu dönemdeki sansür ve yasakların karakteristiğini göstermesi bakımından Kahire'de Şeyh Alizâde Hoca Muhyiddin imzasıyla çıkan Kanûn-ı Esâsî Gazetesi'nin ilk sayısında manifesto niteliğindeki giriş yazısındaki şu ifadelerin meselenin mahiyetini daha iyi anlatacağına inanıyoruz: “...Mizraklı İlmihal'e varıncaya kadar 
şifreli telgraflarla kütüb-i şer'iyyeyi yasaklamaya devam etmenin mânâsı var midır..."

\section{SEYÂHATNÂME`NIN MUZIR GÖRÜLEREK YASAKLANMASI}

İkdâm Gazetesi matbaasında 1896'dan itibaren ilk altı cildi sansür altında basılan Evliyâ Çelebi Seyâhatnâmesi'nin mevcut nüshaları, eser hakkında gazetede de ayrıca neşriyat yapıldığı gerekçesiyle Nisan 1902'de Maârif Nezâreti ile Matbûât-1 Dâhiliye Müdîriyeti müfettişlerince mühürlenerek yasaklanmıştır. Bu konuda önce 30 Mart 1318(12 Nisan 1902)'de Yıldız Sarayı Başkitâbet Dâiresi'nden müsteşarlık makamı vasıtasıyla Matbûât İdâresíne bir müzekkere gönderilip: "bir süredir İkdâm Gazetesi ne gibi zararlı bölümler içerdiği bilinen Evliyâ Çelebi Tarihi hakkında neşriyat yapmakta olup bu neşriyata Matbuat İdaresince izin verilmemesi gerekirken bilakis müsamaha edilmesi mesuliyetli bulunduğundan bundan sonra böyle şeylere dikkat ettirilmesi çıkmış bulunan irâde-i seniyye icabındandır" (BOA DH.MKT 585/3) denilerek gereğinin yapılması istenmiştir. Konuyla ilgilenen Matbûât-1 Dâhiliye Müdürü Mustafa imzasıyla yazılan tezkerede ise "bu gazetede uzun bir süredir Evliyâ Çelebi Tarihi'ne dair bir şey yazllmamış olup kitap ise Maârif Nezâreti'nin denetimi altında peyderpey basılıp neşredilmiş olduğundan durumun bu nezarete bildirilmesi gerekeceğinin ve bununla birlikte ferman gereğince hareket edilerek bu hususta bundan sonra da gazetelere tek bir harf bile yazdırılmayacağının arzına cesaret edilir" (BOA DH.MKT 483/35) denilerek konuya açıklık getirilmiştir. Bu konu Dâhiliye Mektûbî Kalemi'nden bir üst yazıyla Maârif Nezâreti'ne bildirilerek "bu konuda Matbûât-ı Dâhiliye Müdîriyeti'nden verilen tezkere gönderildiği üzere idârece gerekli muâmele îfâsı tabî̀ olup ancak mezkûr kitâb tarafinızca denetlenerek neşredildiğinden ve muzır bölümleri içerdiğinden fermân gereğince sizce de gerekenin yapılması arzolunur" denilerek gereken titizliğin gösterilmesi istenmiştir.

Seyâhatnâme'nin bu yazışmalardan sonra mevcut nüshalarının mühürlenerek yasaklandığını ise yaklaşık 1,5 yıl sonra gazetenin sahibi Ahmed Cevdet tarafından 22 Kânûn-1 Evvel 1319 (4 Ocak 1904) tarihinde

Kanûn-ı Esâsî Gazetesi, 21 Kânûn-ı Evvel 1896(16 Receb 1314) tarihli ilk sayı, Kahire. 
yazılan dilekçeden anlıyoruz. Bu dilekçede şöyle denilmektedir: "Matbaamda basılmış olan Evliyâ Çelebi Seyâhatnâmesi adlı kitabın mevcut nüshaları 1,5 sene önce Maârif Nezâreti ile Matbûât-ı Dâhiliye Müdîriyeti müfettişlerince depomuz dahilinde mühürlenmişti. Muamelenin yapılış şeklinden bunun geçici bir tedbir olduğu anlaşılmakta idiyse de mühürlenmiş kitapların uzun bir süre satılmaktan men'i ve ek olarak depo kirasının da tarafimca ödenip gitmesi mağguriyetimi iyice artırmıştır. Velînimetimiz yüce padişâhımızın rahmetleri daima kullarının üzerinde döndüğ̈̈̈nden bu gibi men edilmiş kitaplar hakkında öteden beri ya yasağın kaldırılıp satışına izin verilmesi ya da zararın giderilmesi yolu izlenmiştir. Dolayısıyla velînimetine geceli gündüzlü hizmet etmekle övünen bu aciz kul hakkında da aynı muamelenin yapılmasın istirham ederim. Mühürlenmiş kitaplarla diğer kitapları tutuldukları depodan çıkarıp başka bir yere nakletmek istesem de bu kitaplarm muhafazası Matbûât İdâresinde korunan bir senetle üzerime yüklenmiş olduğundan bir mesuliyet gelmemesi için durumu bilgilerinize arzederim" (BOA DH.MKT 809/75)

Bu dilekçeye karşıllı Matbûât İdâresi'nce yazılan tezkerede "Bu konuda çıkan irâde-i seniyye bu kitap hakkında gazetelere bir harf bile yazdırlmamasından ibaret olduğundan hükmü derhal icra edilmiş ve Mâarif Nezâreti'nden gelen talep üzerine de mühürlemede tarafimizdan bir müfettiş bulundurulmuştu. Ancak, kitaplarm mühürlenmesi hakkında bu nezârete özel bir emir verilip verilmediği idâremizce bilinmediğinden ve gerçekten de bu kitapların uzun süre orada mühürlü kalması sahibini mağdur edeceğinden kitapların oradan kaldırılması mı yahut bedelinin ödenmesi mi gerekeceğinin bu nezâretten araştırılması gereklidir"(BOA DH.MKT 809/75) denilmiş ve konu bir üst yazıyla Maârif Nezâreti'ne bildirilmiştir. Konuyla ilgili belgeler arasında Maârif Nezâreti'nin bu hususa dair nasıl bir muamele yaptığını gösteren melfuf veya derkenar şeklinde herhangi bir kayıt ve açıklamaya rastlanılmamıştır. Ancak, konuyla ilgili muamelelerin ayrıntılarını gazete sahibi Ahmed Cevdet'in yazdı̆̆ı dilekçeden öğrenebiliyoruz. Yukarıda da belirtildiği üzere, 1902'de genel bir mühürleme ve yasak uygulanmış olup, bu sırada bu eserle ilgili de muamele yapıldığından ayrıca bir yazışma yapılmamış olabilir. 


\section{BELGELER}

1. Dâhiliyye Mektûbî Kalemi. (BOA DH.MKT 483/35)

Maârif Nezâret-i Aliyyesine.

Bir müddetden beri İkdâm Gazetesi Evliyâ Çelebi Tarihi hakkında neşriyyâtda bulunmakda olup bunun ne gibi fıkarât-ı muzırrayı muhtevî olduğu ma'lûm bulunmasına mebnî neşriyyât-1 mezkûreye Matbûât İdâresince müsâade edilmemek lâzım gelir iken bi'l-aks müsâmaha vukûı dâî-i mes'ûliyyet bulunduğundan ba'demâ bu gibi şeylere dikkat etdirilmesi şeref-sudûr buyurulan irâde-i seniyye-i cenâb-1 hilâfet-penâhî iktizâ-yı âlîsinden bulunduğu Mâbeyn-i Humâyûn-1 cenâb-1 mülûkâne Başkitâbet-i celîlesinden bâ-tezkere-i husûsiyye teblîğ kılınmışdır. Bu bâbda Matbûât-1 Dâhiliyye Müdîriyyet-i Behiyyesinden verilen tezkere gönderildiği üzere idârece muâmele-i lâzime îfâsı tabîi olup ancak mezkûr kitâb nezâret-i aliyyelerince muâyene ve tedkîk ile neşrine müsâade ve peyderpey tab' edilmekde bulunmasından ve fıkarât-ı muzırrayı muhtevî olmasından dolayı ber-mantûk-1 emr ü fermân-1 humâyûn-ı hazret-i şehriyârî nezâret-i aliyyelerince de iktizâ-yı hâlin îfâsı husûsuna himem-i aliyyeleri ma'rûzdur. Ol bâbda... 10 Muharrem 1320, 6 Nisan 1318

Bâb-1 Âlî. Nezâret-i Celîle-i Dâhiliyye İdâre-i Matbûât (aded 80)

Bir müddetden beri İkdâm Gazetesi Evliyâ Çelebi Tarihi hakkında neşriyyâtda bulunmakda olup bunun ne gibi fıkarât-1 muzırrayı muhtevî olduğu ma'lûm bulunmasina nazaran neşriyyât-1 mezkûreye Matbûât İdâresince müsâade edilmemek lâzım gelir iken bi'l-aks müsâmaha vukû1 dâî-i mes'ûliyyet bulunduğundan ba'demâ böyle şeylere dikkat etdirilmesi şeref-sudûr buyurulan irâde-i seniyye-i cenâb-1 hilâfet-penâhî iktizâ-yı âlîsinden bulunduğu Mâbeyn-i Humâyûn-1 cenâb-1 mülûkâne Başkitâbet-i celîlesinden bâ-tezkere-i husûsiyye teblî̆g kılındığından ber-mantûk-1 emr ü fermân-1 humâyûn îfâ-yı muâmeleye dikkat olunması makâm-1 âlî-i müsteşârîden teblîğ buyurulan 31 Mart 318 tarihli müzekkerede emr ü iş'âr buyurulmuşdur. Bir haylî vaktden beri zikr olunan gazetede Evliyâ Çelebi Tarihine dâir bir şey yazılmamış ve mezkûr kitâb ise Maârif Nezâret-i 
Aliyyesince muâyene ve tedkîk ile neşrine müsâade ve peyderpey tab' edilmekde bulunmuş olduğundan ve fikarât-1 muzırrayı muhtevî bulunmasından dolayı nezâret-i müşârün-ileyhâya iş'âr-1 keyfiyetle iktizâ-yı hâlin îfâ buyurulması lâzım geleceğinin ve maamâfîh ber-mantûk-1 emr ü fermân-1 humâyûn-1 hazret-i pâdişâhî ba'demâ dahi gazetelere buna dâir harf-i vâhid yazdırılmayacağının arz u beyânına cür'et olunur. Ol bâbda emr ü fermân hazret-i men-lehü'l-emrindir.

Fî 5 Muharrem sene 320 ve fî 1 Nisan sene 318

Matbûat-1 Dâhiliyye Müdîri Mustafa

2. Matbûât-1 Dâhiliyye Müdîriyyet-i Behiyyesine Tezkere (BOA DH.MKT 585/3)

Bir müddetden beri İkdâm Gazetesi Evliyâ Çelebi Tarihi hakkında neşriyyâtda bulunmakda olup bunun ne gibi fıkarât-1 muzırrayı muhtevî olduğu ma'lûm bulunmasına nazaran neşriyyât-1 mezkûreye Matbûât İdâresince müsâade edilmemek lâzım gelir iken bi'l-aks müsâmaha vukûı dâî-i mes'ûliyyet bulunduğundan ba'demâ böyle şeylere dikkat etdirilmesi şeref-sudûr buyurulan irâde-i seniyye-i cenâb-1 hilâfet-penâhî iktizâ-y1 âlîsinden bulunduğu Mâbeyn-i Humâyûn-1 cenâb-1 mülûkâne Başkitâbet-i celîlesinden bâ-tezkere-i husûsiyye teblî̆g kılındığından ber-mantûk-1 emr ü fermân-1 humâyûn îfâ-yı muâmeleye dikkat olunmak üzere işbu tezkere Matbûât-1 Dâhiliyye Müdîriyyet-i Behiyyesine i'tâ edildi (31 Mart sene 318)

\section{Yıldız Sarây-1 Humâyûnu Başkitâbet Dâiresi (71)}

Bir müddetden beri İkdâm Gazetesi Evliyâ Çelebi Tarihi hakkında neşriyyâtda bulunmakda olup bunun ne gibi fıkarât-1 muzırrayı muhtevî olduğu ma'lûm bulunmasına nazaran neşriyyât-1 mezkûreye Matbûât İdâresince müsâade edilmemek lâzım gelir iken bi'l-aks müsâmaha vukûı dâî-i mes'ûliyyet bulunduğundan ba'demâ böyle şeylere dikkat etdirilmesi şeref-sudûr buyurulan irâde-i seniyye-i cenâb-1 hilâfet-penâhî iktizâ-yı âlîsindendir. Ol bâbda emr ü fermân hazret-i men-lehü'l-emrindir. Fî $3 \mathrm{Mu}$ harrem sene 320 ve fî 30 Mart sene 318. Bende. Serkâtib-i Hazret-i Şehriyârî. 
3. İkdâm Gazetesi İdâresi (Dersaâset Bâb-1 Âlî Caddesi) (BOA DH.MKT $809 / 75)$

Dâhiliyye Nezâret-i Celîlesi Cânib-i Âlîsine

Devletlü efendim hazretleri

Matbaa-i âcizânemde tab' edilmiş olan "Evliyâ Çelebi Seyâhatnâmesi" nâmındaki kitâbın nüsah-1 mevcûdesi bir buçuk sene mukaddem Maârif Nezâret-i Celîlesiyle Matbûât-1 Dâhiliyye Müdîriyyet-i Aliyyesi müfettişleri tarafından kendi depomuz dâhilinde mührlenmiş idi. Muâmelenin sûret-i cereyânından bunun bir tedbîr-i muvakkat olduğu anlaşılmakda idiyse de kütüb-i mahtûmenin müddet-i medîde satılmakdan men'i ve zamîmeten depo kirâsının dahi ilâ-âhiri'l-eyyâm âcizleri tarafından tesviye edilip gitmesi mağdûriyet-i kemterânemi lâ-yenkati teşdîd etmekdedir. Velî-ni'met-i bîminnetimiz şevketlü pâdişâhımız efendimiz hazretlerinin merâhim-i seniyye-i mülûkâneleri tebaa-i şâhâneleri kullarının dâimâ mazhar-1 âtıfet ve şefakat olmaları muhîtinde dâir olduğu cihetle bu gibi kütüb-i mahcûre hakkında öteden beri yâ ref'-i memnûiyyetle feth-i bazâr-1 dâd u sitede veyâhûd cebr-i mâ-fât ile izâle-i zarara bezl-i mürüvvet ü âtıfet edilegeldiği hamden sümme şükrâ emsâl-i adîdesiyle sâbitdir. Binâen alâ-zâlik hidmet-i müstelzimü'l-mefharet-i velî-ni'met-i a'zamîye geceli gündüzlü vakf-1 vücûd etmekle mübâhî olan bu kemter kul hakkında deydene-i dîrîne-i saltanat-1 seniyyeden olarak lutf $u$ âtıfetle muâmele buyurulmasını istirhâm ve mevzû1 istirhâm olan kitâbların müddahar bulunduğu depoyu terk ile içindeki kütüb-i sâireyi başka bir mahalle nakl edeceğimden ve halbuki kütüb-i mezkure-i mahtûmenin muhâfazası Matbûât İdâre-i Aliyyesinde hıfz edilen bir sened-i âcizî ile bendelerine tahmîl olunduğundan bir mes'ûliyyet teveccüh etmemek üzere keyfiyeti huzûr-1 sâmî-i cenâb-1 nezâret-penâhîlerine arza mecbûriyet-i mübreme hâsıl olduğunu ifâdeye cür'et eyledim. Ol bâbda emr ü fermân hazret-i veliyyü'l-emrindir.

Fî 22 Kânûn-1 Evvel sene 319

Bende. İkdâm Gazetesi Sâhibi Ahmed Cevdet 
Bâb-1 Âlî. Nezâret-i Celîle-i Dâhiliyye İdâre-i Matbûât (aded 911)

İkdâm Gazetesi sâhib-i imtiyâzı tarafından takdîm kılınup idâre-i âcizîye havâle buyurulan melfûf arzuhâlde matbaasında tab' edilmiş olan Evliyâ Çelebi Seyâhatnâmesi nâmındaki kitâbın nüsah-ı mevcûdesi bir buçuk sene mukaddem Maârif Nezâret-i Celîlesiyle Matbûât müfettişleri tarafından kendi deposunda taht-1 temhîre alındığından ve depo kirâsının müddet-i medîde tarafından tesviye edilip gitmesi mağdûriyetini mûcib olduğundan ve şimdi mezkûr depoda bulunan sâir kitâbları başka bir mahalle nakl eyleyeceğinden bahisle yâ ref'-i memnûiyyeti yâhûd zararının tazmîni istid'â olunuyor.Bu bâbda idâre-i âcizîye teblî̆g buyurulan irâde-i seniyye-i hazret-i pâdişâhî zikr olunan kitâb hakkında gazetelere harf-i vâhid yazdırılmamasından ibâret olarak derhâl infâz-ı hükm-i celîline müsâraat olunmuş ve bi'l-âhire nezâret-i müşârün-ileyhâdan vukû bulan taleb üzerine dahi hîn-i temhîrde idâre-i âcizîden bir müfettiş bulundurulmuş ise de kitâbların taht-1 temhîre alınması hakkında nezâret-i müşârün-ileyhâya bir emr-i mahsûs teblîğ buyurulup buyurulmadığı idâre-i âcizîce mechûl bulunmuş olduğundan ve vâkıâ mezkûr kitâbların müddet-i medîde orada memhûr kalması sâhib-i imtiyâz-1 müşârün-ileyhin mağdûriyetini mûcib olacağından kitâbların oradan kaldırılması mı yâhûd bedelinin tesviyesi mi iktizâ edeceğinin âidiyeti hasebiyle nezâret-i müşârün-ileyhâdan istifsâr buyurulması bâbında emr ü fermân hazret-i men-lehü'l-emrindir.

Fî 18 Şevvâl 321 ve fî 25 Kânûn-1 Evvel sene 319 Matbûât-1 Dâhiliyye Müdîri bende. Mustafa

Dâhiliyye Mektûbî Kalemi.

Maârif Nezâret-i Celîlesine (nr. 1870 27. 25 Şevvâl 321 ve 1 Kânûn-1 sânî 319)

İkdâm Gazetesi sâhib-i imtiyâzı tarafından verilen arzuhalde matbaasında tab' edilmiş olan Evliyâ Çelebi Seyâhatnâmesi nâmındaki kitâbın nüsah-1 mevcûdesi bir buçuk sene mukaddem nezâret-i celîleleriyle Matbûât müfettişleri tarafından kendi deposunda mühr altına alındığından ve depo kirâsının müddet-i medîde tarafından tesviye edilmesi mağdûriyetini mûcib olduğundan ve şimdi mezkûr depoda bulunan sâir kitâbları başka bir mahalle nakl eyleyeceğinden bahisle yâ ref'-i memnûiyyeti yâhûd zararının 
tazmîni istid'â olunmuşdur.Bu bâbda şeref-sâdır olan irâde-i seniyye-i hazret-i pâdişâhî hükm-i celîli zikr olunan kitâb hakkında gazetelere harf-i vâhid yazdırılmamasından ibâret olarak derhâl infâzına müsâraat olunmuş ve bi'l-âhire makâm-1 nezâret-i celîlelerinden vukû bulan taleb üzerine de deponun hîn-i tahtîminde Matbûât-1 Dâhiliyye İdâresinden bir müfettiş bulundurulmuş ise de kitâbların mühr altına alınması hakkında nezâret-i Celîlelerine bir emr-i mahsûs teblî̆g olunup olunmadiğı mechûl bulunduğundan ve vâkıâ mezkûr kitâbların müddet-i medîde orada mühr altında kalması müsted'înin mağdûriyetini mûcib olacağından kitâbların oradan kaldırılması mı yâhûd bedelinin tesviyesi mi iktizâ edeceğinin inbâ buyurulması husûsunun idâre-i mezkûre ifadesiyle beyânına ibtidâr edildi ol bâbda. 


\section{KAYNAKÇA}

Demirel, Fatmagül (2007), II.Abdülhamid Döneminde Sansür, Bağlam Yayınları, İstanbul.

Demirel, Fatmagül (2005), II. Abdülhamit döneminde gümrüklerde el konulan (ve elbette yakılan) kitaplar", Müteferrika, s. 26, 2005.

Demirel, Fatmagül-Çavaş, Raşit (2005), yeni bulunan belgelerin ışı̆̆ında II. Abdülhamid'in yaktırdığg kitapların bir listesi, Müteferrika, s. 28, ss.3-24.

Demirel, Fatmagül (2009), II. Abdülhamid döneminde yazar ve yayıncı olmak: Yasak kitaplar!, Düne bakarak bugünü anlamak: 2008'den 1908'e bakmak. Yayına hazırlayan: Mutlu Dursun-Tutku Vardağlı, İstanbul: Tarem yayınları.

Demirel, Fatmagül (2005), II. Abdülhamid döneminde yasak yayınlar, Books and reading in the ottoman world, 10th annual workshop on ottoman material culture, Boğaziçi Üniversitesi, October 14-15.

Ortaylı, İlber (1995), İmparatorluğun En Uzun Yüzyılı, Hil yayınları, İstanbul.

BOA MF.TTD (Başbakanlık Osmanlı Arşivi Maârif Nezâreti Telif ve Tercüme Dairesi)

BOA, Y.PRK.MF (Başbakanlık Osmanlı Arşivi Yıldız Perakende Maârif)

BOA Y.MTV (Başbakanlık Osmanlı Arşivi Yıldız Mütenevvi Maruzat)

Kânûn-1 Esâsî Gazetesi, 21 Kânûn-1 Evvel 1896, Kahire. 